\title{
Participatory Evaluation and Promotion of Improved Bread Wheat Technology in the Dry lands of Wag-lasta, Ethiopia: Challenges and Prospects
}

\author{
Ademe Abera Mihiretu ${ }^{1}$
}

\begin{abstract}
This study was conducted to evaluate the comparative advantage, farmers' preference and stakeholders' linkage in bread wheat technology, involving 100 farmers in Wag-lasta, Ethiopia. Both quantitative and qualitative research approaches were used to compare the improved technology with the local practice. Cost-benefit ratio, descriptive and inferential statistics were employed for quantitative analysis. Farmers' technology preference and stakeholders' linkage were assessed using Likert scale and SWOT analysis. The improved technology had $116.7 \%$ yield advantage over the local practice and was economically profitable. Nonetheless, the farmers were describing that full package application was tough due to lack of practical training, package complication and labor shortage in descending order. Except resistance to pest, most farmers had positive attitude towards identified preference parameters. Strengths and weaknesses of stakeholders in the promotion were recognized matching with opportunities and threats. Therefore, the improved technology is suggested for wider diffusion in the study area. Providing extension and training, on top of identifying viable sources and multiplying cooperatives to the technology would enhance the farmers' uptake.
\end{abstract}

Keywords: Bread wheat; Cost-benefit ratio; Preference; Stakeholder linkage; SWOT analysis; Ethiopia.

\section{INTRODUCTION}

In Ethiopia, wheat grows in humid and sub-humid agro ecological zones of the highland temperate mixed farming system. The land under wheat cultivation was expanded from 1.4 to 2.6 million hectare since 2004 , and the production was also increased by 2.9 million tons in the last fifteen years (CSA, 2019). It is cultivated annually on 1.66 million hectare in Ethiopia with a total production of 4.23 million tons and an average productivity of 2.54 ton $\mathrm{ha}^{-1}$. This makes the country the second largest wheat producer in sub-Saharan Africa (CSA, 2019).

The national average productivity of wheat is below the east African average with a range of $11-12 \%$. It is also inferior to the African and the world average by $23 \%$

\footnotetext{
${ }^{1}$ Associate Researcher in Agricultural Extension, Socio Economic and Agricultural Extension Research Directorate, Sekota Dry-land Agricultural Research Centre, Ethiopia
}

Received : 14-01-2020; Accepted : 05-03-2020 
Participatory Evaluation and Promotion of Improved Bread Wheat Technology in the Dry lands of Wag-lasta, Ethiopia: Challenges and Prospects

and $44 \%$, respectively. The domestic wheat production accounts 79 per cent of local supply while the rest is imported (CSA, 2017). Major wheat producing areas in Ethiopia are Arsi, Bale, Shewa, Ilubabor, Western Hareghe, Sidamo, Northern Gondar, and Gojam zones. Amhara region accounts for 529826.54 hectare area coverage under wheat and 1195986.83 ton of total production with an average productivity of 2.36 ton ha-1 (CSA, 2019). Eastern Amhara especially North Wollo zone is in the highland agro ecology suitable to wheat production. North Wollo zone accounts $4.30 \%$ of total wheat production in the region, which makes one of the major wheat producing zone in Amhara region next to East Gojam, North Gonder and South Wollo zones (CSA, 2019). However, its productivity is far below the crop's potential mainly due to biotic and abiotic constraint. More specifically, due to low soil fertility, absence of improved wheat varieties, and other inputs such as less utilization of fertilizer and lack of decent management in general (Ademe and Asmiro, 2018).

To overcome this problem, Sekota Dry-land Agricultural Research Center in its Crop Research Directorate had been adapting different bread wheat varieties and recommended the best performing and preferred variety called "hawi" with its technology packages to Lasta areas of North Wollo in Eastern Amhara. The new bread wheat technology ${ }^{1}$ was demonstrated on farmers' small plot, and then farmers evaluate the technology from socioeconomic and agro ecological perspectives. They were hence highly interested with its performance and pursuing to cultivate and use the technology for future. This circumstance dictated the Agricultural extension researchers to promote and upscale the technology in wider-scale trough creating and strengthening linkage among possible stakeholders. Specifically, the study intended to assess the comparative advantage of improved bread wheat technology over the local practice, to examine farmers' reaction and demand on the improved technology and finally to assess the strengths, weaknesses, opportunities and threats of possible actors in the extension system.

\section{METHODOLOGY}

\section{Study area}

The study was conducted in the potential areas of Lasta district in Northeast Amhara region, Ethiopia, for two consecutive production years (2016-2017). The district located at an altitude of 2400 meters above sea level having annual rainfall of $895.2 \mathrm{~mm}$ and average temperature of $26.2^{\circ} \mathrm{C}$. The dominant soil type of the district is black sandy and loam (Mihiretu, Asresu and Wabet, 2019).

\section{Sampling and experimental procedure}

In this study, the improved bread wheat technology was promoted in comparison with

\footnotetext{
${ }^{1}$ In this study 'bread wheat technology' stands for full package application (using improved bread wheat variety with its recommended fertilizer and seed rates, on optimally tilled farms, in row and timely sowing as well as proper weed and pest management)
} 
Table 1.

Duties and Responsibilities of Stakeholders in Bread Wheat Technology Promotion and Diffusion in Lasta district

\begin{tabular}{|l|l|l|}
\hline \multirow{2}{*}{ Researchers } & $\begin{array}{l}\text { Preparing manuals and provide training for farmers and experts } \\
\text { Confirm selected cluster farms and deliver seed on time } \\
\text { Offer technical support to farmers and experts } \\
\text { Organizing field days with district Agriculture Offices }\end{array}$ \\
\hline \multirow{2}{*}{$\begin{array}{l}\text { Experts from } \\
\text { Agriculture }\end{array}$} & $\begin{array}{l}\text { Office } \\
\text { in }\end{array}$ & $\begin{array}{l}\text { Participate in workshops and trainings } \\
\text { Provide technical support in farm and farmer selection } \\
\text { Monitor the activities and participate in field days }\end{array}$ \\
\cline { 2 - 3 } & $\begin{array}{l}\text { Select clustered farms and measure the size using GPS } \\
\text { Provide technical support in technology application } \\
\text { Provide information to researchers on disease outbreaks } \\
\text { Facilitate farmers' seed exchange system }\end{array}$ \\
\hline Farmers & $\begin{array}{l}\text { Collect fertilizer and prepare the farm to the optimum level } \\
\text { Planting on time, managing weed and harvest on time } \\
\text { Keeping seed quality to give back to the source center } \\
\text { Exchange the seed to interested farmers in any arrangement }\end{array}$ \\
\hline
\end{tabular}

Note: SMS', Subject Matter Specialists; DAs, Development Agents

local production practice through scale-wide participatory approach. In the first stage, Lasta district was purposively selected by its production potential in moisture deficit areas of northeastern Amhara region. In the second stage, 100 farmers who were willing to allocate $0.25-0.50$ hectare of clustered land for the experiment were selected. Before launching the experiment, researchers organized operational platform to create awareness, share duties, and responsibilities among concerned stakeholders (Table 1). To strengthen the awareness level, farmers and experts were provided basic agronomic training on the improved bread wheat technology in particular and the extension approach in general. Planting of improved wheat technology was in row using $110 \mathrm{~kg} \mathrm{ha}^{-1}$ seed rate. Urea and $\mathrm{Di}$-ammonium phosphate (DAP) fertilizers were applied at the rates of 50 and $100 \mathrm{~kg} \mathrm{ha}^{-1}$, respectively. However, the local farmers practice was sown in broadcast using $150 \mathrm{~kg} \mathrm{ha}^{-1}$ seed rate and without fertilizer. Cluster approach was preferred, because it helps to create competition among farmers in field management, pest and disease control. Moreover, it attracts the eyes of neighbor farmers thereby inspire them to ask, observe 
Participatory Evaluation and Promotion of Improved Bread Wheat Technology in the Dry lands of Wag-lasta, Ethiopia: Challenges and Prospects

and finally to accept the technology (Feder et al., 1985). Finally, extension activities like field days and diagnostic visits were performed to create awareness about the technology thereby to benefit the farmers in the end.

\section{Data collection and analysis}

Both quantitative and qualitative data were collected. Quantitative data such as grain and biomass yields of the technologies were collected at farm level using quadrant while farmers' socioeconomic features were collected employing structured questionnaire (Mihiretu and Assefa, 2019). Economic data, such as variable costs of fertilizer, seed and labour were collected using questionnaire, while the economic data was estimated from grain and biomass yields using the farm gate price. However, qualitative data such as farmers' reaction and demand of the technology were collected with unstructured open-ended questions. Secondary data was collected from different published and unpublished sources.

The quantitative data were analyzed using simple descriptive statistics (viz., percentage, mean and standard deviation). Paired sample t-test was used to observe the yield significance between the improved technology and local practice (Mihiretu et al., 2019a). Likewise, the benefit-cost ratio analysis was used to analyse the comparative advantage of improved technology over the local practice. Farmers' reaction and demand to the technology were assessed in Likert scale rating method. Cronbach's alpha test was employed to assess the internal consistency among opinion obtained through multiple
Likert-type items. Besides, thematic oriented narration was used to describe information obtained from focus group discussions (FGDs) (Mihiretu, Eric and Lemma, 2019).

Moreover, SWOT analysis was used to assess the external and internal environments of stakeholders in the extension system. It was used to specify and categorize stakeholders' strengths and weaknesses as well as opportunities and threats. This can finally help stakeholders to develop strategies based on strengths and vanishing weaknesses, as well as to gain maximum profit using opportunities and offsetting the threats (Ibrahim et al., 2019).

\section{FINDINGS AND DISCUSSION}

\section{Characteristics of participant farmers and farms}

The average age of participant farmers in bread wheat technology promotion was 42.10 with mean farming experience of 21.20 years, which shows that they were in active age strata, enabling them to understand the new technology. Among participant farmers, 23.10 per cent were female-headed while the rest were male-headed households with the average family size of 3.9. Likewise, more than half $(59.10 \%)$ of the participant farmers were not going to school. All participant farmers were got training, but $25.60 \%$ agreed that the training provided was not adequate to apply the technology package. Tilling frequency of farms governs the productivity of any crop technology; so that the agronomic findings suggest that 'three times tilling is an optimum level' for bread wheat technology. Accordingly, 
Table 2.

Characteristics of Participant Farmers and their Farms in Lasta district

$(n=100)$

\begin{tabular}{|c|c|c|c|}
\hline Category & Variables & Indicator & Estimates \\
\hline \multirow{5}{*}{$\begin{array}{l}\text { Demographic } \\
\text { characteristics }\end{array}$} & Gender of the head of the household (\%) & $\begin{array}{l}\text { Male } \\
\text { Female }\end{array}$ & $\begin{array}{l}76.90 \\
23.10\end{array}$ \\
\hline & Age of the head of the household (years) & $\begin{array}{l}\text { Mean } \\
\text { S.D }\end{array}$ & $\begin{array}{l}42.10 \\
10.41\end{array}$ \\
\hline & $\begin{array}{l}\text { Educational level of the head of the } \\
\text { household (\%) }\end{array}$ & $\begin{array}{l}\text { Literate } \\
\text { Illiterate }\end{array}$ & $\begin{array}{l}40.90 \\
59.10\end{array}$ \\
\hline & $\begin{array}{l}\text { Farming experience of the head of } \\
\text { household (years) }\end{array}$ & $\begin{array}{l}\text { Mean } \\
\text { S.D }\end{array}$ & $\begin{array}{c}21.20 \\
8.54\end{array}$ \\
\hline & Family size of the household & $\begin{array}{l}\text { Mean } \\
\text { S.D }\end{array}$ & $\begin{array}{l}3.90 \\
2.34\end{array}$ \\
\hline \multirow{4}{*}{$\begin{array}{l}\text { Improved } \\
\text { wheat } \\
\text { technology } \\
\text { production } \\
\text { characteristics }\end{array}$} & $\begin{array}{l}\text { Size of land allocated for wheat technology } \\
\text { (ha) }\end{array}$ & $\begin{array}{l}\text { Mean } \\
\text { S.D }\end{array}$ & $\begin{array}{l}0.25 \\
0.14\end{array}$ \\
\hline & Farm tillage frequency (\%) & $\begin{array}{l}\geq 3 x \\
<3 x\end{array}$ & $\begin{array}{l}78.50 \\
21.50\end{array}$ \\
\hline & Planting was on time (\%) & $\begin{array}{l}\text { Yes } \\
\text { No }\end{array}$ & $\begin{array}{c}94.10 \\
5.90 \\
\end{array}$ \\
\hline & Weed management was on critical time (\%) & $\begin{array}{l}\text { Yes } \\
\text { No }\end{array}$ & $\begin{array}{l}91.80 \\
8.20\end{array}$ \\
\hline \multirow{2}{*}{$\begin{array}{l}\text { Access to } \\
\text { agricultural } \\
\text { services }\end{array}$} & The training provided was sufficient (\%) & $\begin{array}{l}\text { Yes } \\
\text { No }\end{array}$ & $\begin{array}{l}74.40 \\
25.60 \\
\end{array}$ \\
\hline & The follow up of experts was adequate (\%) & $\begin{array}{l}\text { Yes } \\
\text { No }\end{array}$ & $\begin{array}{c}93.80 \\
6.20\end{array}$ \\
\hline
\end{tabular}

\section{S.D: Standard Deviation}

78.50\% of farmers involved in the promotion were tilling their land beyond and at sufficient level, while the remaining tilled below the optimum. This tillage difference was observed due to household's dissimilarity in access to draft animals, labor, as well as soil gradient and slope variance of farms that farmers owned. Moreover, timely completion of agronomic activities has a direct effect on crop technology's productivity. Hence, 94.10\% 
Participatory Evaluation and Promotion of Improved Bread Wheat Technology in the Dry lands of Wag-lasta, Ethiopia: Challenges and Prospects

and $91.80 \%$ of farmers were planting on critical time and had good weed management, respectively.

\section{Performance and efficiency of improved bread wheat technology}

Yield is main criterion of farmers in adopting any crop technology. The combined analysis result revealed that the productivity of hawi improved bread wheat technology was better than the local practice. The mean yield of improved bread wheat technology was $2600 \mathrm{~kg} \mathrm{ha}^{-1}$ hence it had asignificant yield increment of $1400 \mathrm{~kg} \mathrm{ha}^{-1}$ from the local average production $\left(1200 \mathrm{~kg} \mathrm{ha}^{-1}\right)(p<0.01)$. Therefore, the use of hawi improved bread wheat with its technology packages had a yield advantage of 116.60 per cent over the local bread wheat production. In addition, the average straw biomass of $3688.7 \mathrm{~kg} \mathrm{ha}^{-1}$ obtained from the improved technology was greater than the local practice. The improved bread wheat technology had a significant straw biomass yield advantage of 79.10 per cent over the local production practice in the study area $(p<0.01)$. This actual yield variation in grain and biomass might be due to differences in sowing date, fertilizer and other package components used for the improved technology.

Production costs that are fixed for both improved and local wheat production practices were not calculated because they were similar and thus have no effect among treatments (Mihiretu \& Assefa, 2019). Given the prevailing farm gate prices, the benefitcost ratio was computed on hectare basis.
The variable costs of improved and local bread wheat production practices were ETB 5885 and 3750 , respectively. The farmers were able to generate a gross margin of ETB 59410.1 and 26414.8 from the improved and local bread wheat technologies, respectively (Table 4). Therefore, the cost-benefit ratio result revealed that though both production practices are profitable, adopting the improved bread wheat technology could make the highest profit (ETB11.8) after covering costs. This finding conveys that using improved bread wheat technology in Lasta district is promising and profitable compared to the existing local production practice. With regard to technology profitability, FGD participant farmers stated that:

The improved bread wheat technology is economically efficient as it reduces the seed rate by 36.40 per cent from the conventional production practice on a hectare basis. This is to mean that the improved technology uses a seed rate of $110 \mathrm{~kg} \mathrm{ha} 1$ while the local practice uses $150 \mathrm{~kg} \mathrm{ha}^{-1}$. [FGD, 21/03/2017].

\section{Farmers' preference and demand for improved bread wheat technology}

As described in Table 3, except for resistance to pest most farmers had positive view to the rest of preference parameters. In general, the responses average score is 4.1. This average score implies that farmers perceived and accepted the improved bread wheat technology with full confidence. 
Table 3.

Farmers' Perception and Demand to the Improved Bread Wheat Technology

$(n=100)$

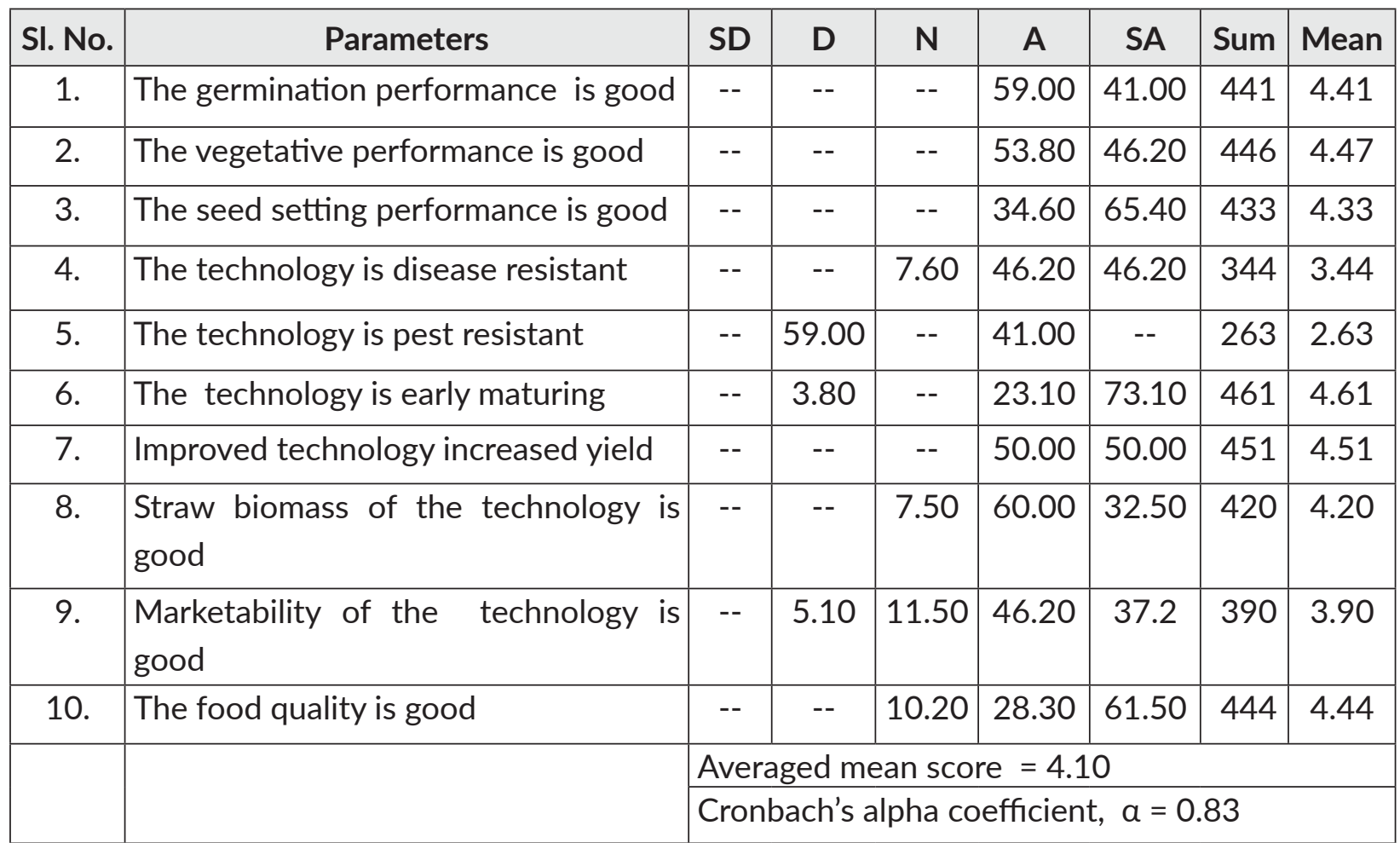

Note: Values are in percentage points; SD: Strongly Disagree, D: Disagree, N: Neutral, A: Agree, SA: Strongly Agree

With regard to resistance to pest, FGD participant farmers revealed that:

The improved technology is poor in pest resistance. However, in terms of maturity the farmers said that it was early maturing because "planted lately as it has to be sown in good moisture but reaped as early as the local". Besides, the improved technology has higher market demand for its big and white seed, on top of its bread baking quality [FGD, 23/02/2017].

Moreover, reliability test was carried out for internal consistency among 12 perception items in Likert scale. The statistics table gives a coefficient score over 0.7 tells higher internal consistency. In this case, $a=$ 0.83 , revealing that items are reliable and appeared to be worthy of retention. Among participant farmers, 85.90 per cent were highly interested to use the bread wheat technology by next year. Likewise, 85.50 per cent of the participants recommended other eligible neighbor farmers to use the technology by reporting the merits via storytelling, physical invitation to visit and using both approaches. Therefore, 85.90 per cent were positive to use in the future while the rest will not take due to labor shortage though they were pleased with the technology. 
Participatory Evaluation and Promotion of Improved Bread Wheat Technology in the Dry lands of Wag-lasta, Ethiopia: Challenges and Prospects

Constraints of full package application in bread wheat technology

Among factors, ease in application of technology is playing significant role in technology adoption. Thus, with follow up by researchers and experts, most of the farmers were applied the full technology package but 55.20 per cent of them described package application in general and row sowing in particular was tough. This is due to lack of practical training, complexity of the technology, labor shortage in main agronomic periods, as well as a combination of lack of practical training and labor shortage in descending order. However, almost all farmers agreed that technology application as per the recommendation is very helpful to increase yield and yield components.

\section{Linkages, technology diffusion and exchange system}

Distribution of duties among stakeholders would consolidate the triple linkages of farmers-extension-research for sustainable technology promotion. As a result, agricultural experts at different levels were handling tasks to facilitate technology dissemination via continuous follow up, technical support, and consultation. At the end of experiment, field day was organized involving 540 participant farmers, agricultural experts, NGOs, and political leaders. Stakeholders who were participated in the field day, showed full interest and took lesson to work in alliance for the benefit of resource poor smallholder farmers. Likewise, clustering approach was appreciated as it creates competition among farmers on farm management as well as for its "eye catching power" to impress individuals around the demonstration plots.

Among the methods used for wider dissemination of improved technologies, solid seed exchange system takes the front line. Participant farmers thus shared the technology with interested farmers in and outside the village via different exchange arrangements (Table 4). Hence, participant farmers shared $880 \mathrm{~kg}$ bread wheat seed with fellow farmers. Food and Agriculture Organization (NGO) has distributed $1380 \mathrm{~kg}$ improved bread wheat to similar agro-ecologies using earlier farmers as a source. Generally, the cooperation among concerned actors in the promotion process boosted compared to the preceding years.

Table 4.

Improved Bread Wheat Technology Exchange and Dissemination in Lasta district

$(n=100)$

\begin{tabular}{|l|c|c|c|c|c|}
\hline & Farmers shared & \multicolumn{2}{|c|}{ Recipient farmers } & Quantity exchanged (kg) \\
\cline { 3 - 5 } & the technology & Inside village & Outside village & Farmers & NGOs \\
\hline Frequency & 68 & 180 & 125 & 880 & 1380 \\
\hline Percentage & 68 & 59.1 & 40.9 & & \\
\hline
\end{tabular}

Source: Own survey computation (2016-2017) 
Finally, closing workshop was organized involving stakeholders like seed enterprises, agriculture development offices and NGOs engaged in the sector to devise ways to forward the technology to wider community in sustainable manner. In this regard, farmers advised to use their 1:5 administrative grouping to

Table 5.

SWOT Analysis of Actors in Bread Wheat Technology Promotion and Diffusion Process

\begin{tabular}{|c|c|}
\hline List of strengths, weaknesses, opportunities and threats & Actors \\
\hline Strengths & \\
\hline $\begin{array}{l}\text { - Being optimist and higher demand for new technology } \\
\text { - Good contact amongst throughout the process } \\
\text { - Sowing in cluster using the package } \\
\text { - Including NGOs as actors in the process } \\
\text { - Become seed sources for the technology } \\
\text { - } \text { Availing inputs and providing training on time } \\
\text { - Collecting and analyzing necessary data }\end{array}$ & $\begin{array}{l}\mathrm{F} \\
\mathrm{F}, \mathrm{E}, \mathrm{R} \\
\mathrm{F} \\
\mathrm{R} \\
\mathrm{F} \\
\mathrm{R} \\
\mathrm{R}\end{array}$ \\
\hline Weaknesses & \\
\hline $\begin{array}{l}\text { - Inadequate follow up from nearby actors } \\
\text { - Gap in full package application } \\
\text { - Problem in maintaining the seed quality } \\
\text { - Stumpy technical backup to farmers } \\
\text { - Unwilling to weed at optimum level }\end{array}$ & $\begin{array}{l}E \\
F \\
F \\
E, R \\
F\end{array}$ \\
\hline Opportunities & \\
\hline $\begin{array}{l}\text { - Existence of NGOs working on technology promotion in area } \\
\text { - Improved technology usage become focus of the government } \\
\text { - Farmers' have good experience on bread wheat production } \\
\text { - Existence of seed exchange culture in the community }\end{array}$ & \\
\hline Threats & \\
\hline $\begin{array}{l}\text { - Being dry-land, has low and erratic rainfall and high temperature } \\
\text { - High risk of drought within } 3 / 4 \text { years interval } \\
\text { - Lower input access due to expensive cost } \\
\text { - Increasing relief aid dependency, especially PSNP }\end{array}$ & \\
\hline
\end{tabular}

Note: F, farmers; $E$, experts and $R$, researchers 
Participatory Evaluation and Promotion of Improved Bread Wheat Technology in the Dry lands of Wag-lasta, Ethiopia: Challenges and Prospects

handover the technology to neighbors and peers easily.

\section{SWOT analysis of stakeholders' linkage}

Appropriate distribution of duties among stakeholders would consolidate linkage in the extension system. Like many other sectors, the success of diffusing bread wheat technology depends on both internal and external factors. Thus, there is a need to identify the strengths and weaknesses in the promotion and diffusion process to match with the opportunities and threats using the SWOT analysis. Data presented in Table 5, presents the strengths, weaknesses, opportunities and threats of stakeholders in bread wheat technology promotion and diffusion.

\section{CONCLUSION}

Except forpestresistance, mostfarmers had positive view to technology preference parameters. In addition, famers and extension workers appreciate the improved bread wheat technology for its economic and societal suitability than the conventional production practice. These stakeholders shared the improved technology with interested farmers in and outside their village using different exchange arrangements. Nevertheless, more than half of farmers described technology package application was tough due to lack of practical training, complication of technology, labor shortage, as well as combination of lack of practical training and labor shortage in descending order.

Based on the findings, there is a need to scale out the improved bread wheat technology to similar agro-ecological conditions in moisture deficit areas of Northeast Amhara. Both government and non-governmental organization should provide appropriate technical and input support services to facilitate the promotion and diffusion process. Extension agents should also use different frontline demonstration extension methods such as observatory, clustering, mass media and farmer trainings to ensure the effective use of limited resources, personnel, time and finance on top of ensuring farmers' active participation. Similarly, establishing seed producing and marketing cooperatives would play a vibrant role in make technology multiplication and exchange system viable to satisfy emerging demands. The SWOT analysis accordingly revealed that actors in agricultural extension system had both positive and negative performances in accomplishing shared duties and responsibilities. As a result, agricultural experts at different levels should use strengths and opportunities of actors to overcome the weaknesses and avoid threats in technology promotion and dissemination. Finally, the extension agents should go beyond technology supply to advance skill and knowledge of farmers for sustainable agricultural and rural development.

\section{REFERENCES}

Ademe, M. \& Asmiro, A. (2018). Pre-Scaling up of Improved Bread Wheat Technology in Moisture Deficit Areas of Wag-lasta, North Eastern Amhara. Proceedings of the 9th Annual Regional Conference on Completed Research Activities of SocioEconomics and Agricultural Extension Research, March 9-20, 2015. Bahir Dar, Ethiopia. 
CSA (2017). Report on area under production of major crops Volume I, Agricultural sample survey, Statistical bulletin 584, The Federal Democratic Republic of Ethiopia, Addis Ababa. Retrieved from http://www.csa.gov.et/ehioinfointernal?download=771:report-on-areaand-production-of-major-crops-2009-e-cmeher-season

CSA (2019). Report on area under production of major crops Volume II, Agricultural sample survey, Statistical bulletin 592, The Federal Democratic Republic of Ethiopia, Addis Ababa. Retrieved from http://www.csa.gov.et/ehioinfointernal?download=821:report-on-areaand-production-of-major-crops-2011-e-cmeher-season

Feder G., Just R. \& Zilberman D. (1985). Adoption of agricultural innovations in developing countries: a survey. Economic Development and Cultural Change, 33 (2), 255-298.

Ibrahim M., Alaa M., Hamed E. \& SalahSaid A. (2019). Environmental SWOT
Analysis for Agricultural Extension in North Sinai Governorate, Egypt. Turkish Journal of Agriculture - Food Science and Technology 7(10), 1503-1508. DOI: https:// doi.org/10.24925/turjaf.v7i10.15031508.2216

Mihiretu A., Asresu M. \& Wubet A. (2019a). Participatory assessment of lentil (Lens culinaris Medik.) production practices in marginal dry lands of Wag-lasta, Ethiopia. Archives of Agriculture and Environmental Science, 4 (3), 288-294.

Mihiretu A., Eric N. \& Lemma T. (2019b). Determinants of adaptation choices to climate change in agro-pastoral dry lands of Northeastern Amhara, Ethiopia. Cogent Environmental Science, 5: 1636548.

Mihiretu, A. \& Assefa, N. (2019). Comparative Evaluation and Demonstration of Field Pea Production Practices in Intermediate Altitudes of Northeastern Amhara, Ethiopia. Turkish Journal of Agriculture - Food Science and Technology, 7(11), 1901-1907. 